\title{
MINERALOGICAL AND RADIOACTIVE CHARACTERIZATION OF GABAL EL-URF PEGMATITES, CENTRAL EASTERN DESERT, EGYPT
}

\section{ANAS M. EL-SHERIF}

Nuclear Materials Authority, P. O. Box 530, El-Maadi, Cairo, Egypt

\section{ABSTRACT}

The present study deals with the mineralogical and radioactive characteristics of the pegmatitic rocks at Gabal El-Urf area, Central Eastern Desert of Egypt.

The zoned pegmatites of El-Urf area are composed of three enriched mineral zones; extremely milky quartz core, intermediate mica zone and feldspars wall zone.

The identified separated heavy minerals in the studied pegmatite can be grouped into three mineral groups; the primary minerals (pyrite, molybdenite, rutile, magnetite, thorianite, zircon, columbite and garnet), the secondary minerals (uranophane, kasolite, uranothorite, samarskite, uranopolycrase, dravite, ilmenorutile, allanite and titanite.) and the gangue minerals (lanarkite, barite, hematite, ilmenite, goethite, apatite, monazite and kamitugaite).

The studied zoned pegmatites hosting or acting as a source for uranium and rare metals ( $\mathrm{Zr}, \mathrm{Y}, \mathrm{Nb}$ and Th) mineralizations. Multistage deformation, magmatic and hydrothermal processes accompanied by events of uranium mineralization with the associated rare metals mineralizations in different episodes affected Gabal El-Urf zoned pegmatites.

The rare metals can be originated through magmatic and hydrothermal fluids under the restrictive sets of conditions that commonly prevail in these zoned pegmatites. The magmatic and hydrothermal processes enriched with rare metals mineralization accompanied by event of an intensive tectonic structure affected Gabal El-Urf pegmatites.

\section{INTRODUCTION}

Gabal El-Urf area is located in Central Eastern Desert between Latitudes $26^{\circ} 37^{\prime}$ and $26^{\circ} 45^{\prime}$ $\mathrm{N}$ and Longitudes $33^{\circ} 20^{\prime}$ and $33^{\circ} 30^{\prime} \mathrm{E}$ covering an area of about $230 \mathrm{Km}^{2}$, (Fig.1). The radioactive anomalies in the area were firstly discovered by El-Tahir (1978).

Field relationships and observations confirm the presence of some different rock types; older granitoids, younger gabbros, younger granites and post-granitic dikes and veins.

The area was extensively studied by many workers since it was discovered by El-Taher (1978). Several geological and radiometric studies were carried out in order to explore the uranium mineralizations as Habib (1982), Bishady et al., (1999), Abdel Ghani (2001), El-Mansi and Dardier (2005), El-Azab (2011), Khamis (2012), Asran et al., (2013) and Khaleal (2013).

The present paper deals mainly with the mineralogy and radioactivity of the pegmatitic rocks and throws more light on the mode of formation of the radioactive mineralizations.

\section{GEOLOGIC SETTING}

The Precambrian basement rocks in the mapped area, are represented by the older granitoids, younger gabbros, younger granites, pegmatites as well as the post granitic dykes and veins.

Older granitoids form low to moderate topographic relief and are intruded by younger gabbros and younger granites with sharp intrusive contact (Fig.2a). They ranging in composition from quartz diorite to granodiorite. Older granitoids are medium to coarse grained with gray to grayish pink colour and show gneissose structure. They are characterized by the bouldary appearance, cavernous weathering, exfoliation and monumental shapes. They are highly fractured and jointed. These rocks are quarried as building stones especially the massive rocks at the eastern part of Gabal El-Urf. They are dissected by numerous dike swarms and pegmatite bodies of different composition and attitudes.

The younger gabbros crop out at Wadi Abu Zawal to the west Gabal El Urf. They occur as low to moderate relief of small rounded or elongated bodies. They are intruded by the younger granites of Gabal El-Urf with intrusive sharp contact. They are of blocky appearance and characterized by black to gray colour, sometimes showing rhythmic layering (Fig.2b). 


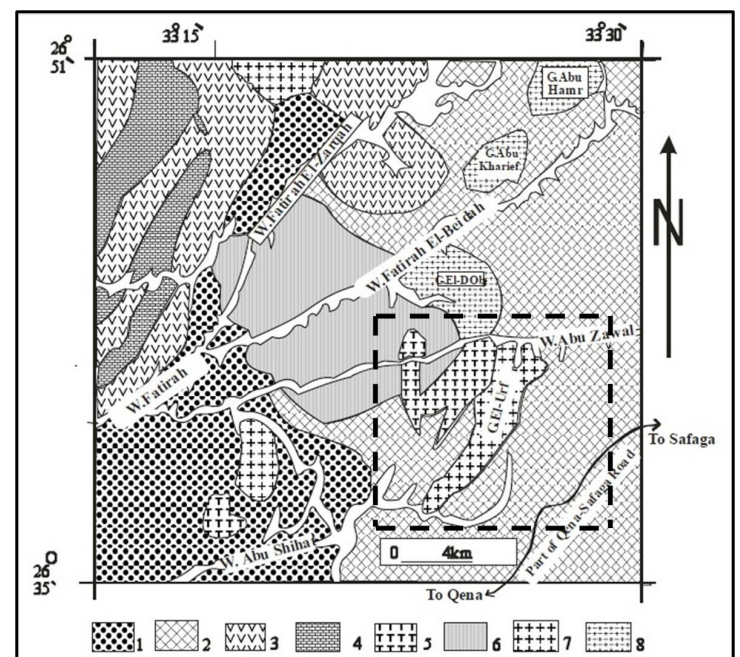

Fig.(1): Geologic Map of EI-Urf area, CentralEastern Desert, Egypt, (Asran et al., 2013). The dashed square is the studied area.

(1) Metavolcanics. (2) Older granitoids.

(3) Dokhan volcanics. (4) Metasediments.

(5) Younger gabbros. (6) Monzogranites.

(7) Syenogranites. (8) Alkali feldspar granites.

The younger granites are represented mainly by Gabal El-Urf and Gabal El-Dob. These younger granites can be easily differentiated into three main phases; monzogranites, syenogranites and alkali feldspar granites.

Gabal El-Dob is exposed as a small lenticular mass $(0.8 \times 0.6 \mathrm{~km})$ trending NNE-SSW and intruding the older granitoids (Fig.2c). It forms zonal composition ranging from monzogranite in the outer rim to alkali feldspar granite in the core. These younger granites are coarse grained and heterogeneous in grain size. They are composed mainly of quartz, plagioclase and alkali feldspar with biotite and reibeckite as mafic minerals. These granites are traversed by faults trending NNE and NW and cut by dike swarms and quartz veins.

Gabal El-Urf is exposed as elongated mass in NNE-SSW direction for a length of about 14 $\mathrm{km}$ and width ranging from $600 \mathrm{~m}$ to more than $2 \mathrm{~km}$. The younger granites of G. El Urf are pink in colour, medium to coarse grained, moderate to high topography. They intrude the older granitoids and younger gabbros with sharp contact (Fig.2a) sending off-shoots and pegmatite bodies into them (Fig.2d). They also carry xenoliths from them ranging in size from few centimeters to few meters. These granites are characterized by well-developed joint sets either as vertical or horizontal jointing. They are highly sheared and dissected by numerous faults and by several dike swarms in different directions. These dyke swarms can be differentiated into felsic and basic dykes.

Felsite and aplite dike swarms are found cutting both the older and younger granites of relatively great extension (Fig.2e). They are mostly trending in two main directions NNE-SSW and NW-SE and dipping SSW and NE respectively. They are hard, massive, highly jointed and sometimes sheeted in their direction.

Basic dike swarms are also dissecting the older and younger granites. They are mostly trending in NW-SE direction with vertical or steep dips to the NE. They are blackish green to black in colour, fine to medium grained and porphyritic in texture. They are of basaltic and doleritic composition and usually show union weathering.

Pegmatites are intruded mainly in the older granitoids and younger granites, especially along their contacts, to which are genetically related. They occur as rounded, elongated, lenticular and irregular shapes varying in size from few meters to hundred meters. They are coarse to very coarse grained and of granitic composition. They are differentiated into zoned and unzoned types.

Abu Zawal pegmatite body intruded in the quartz diorites northeast Gabal El-Urf at the intersection between Latitude $26^{\circ} 43^{\prime} 48^{\prime \prime} \mathrm{N}$ and Longitude $33^{\circ} 29^{\prime} 28^{\prime \prime} \mathrm{E}$. It is elongated dike-like body with about $500 \mathrm{~m}$ in length and about 100 $\mathrm{m}$ in height (Fig. 2f). Occasionally, it contains black radioactive minerals as disseminations and fracture fillings (Fig.2g) and flakes of mica which present in pockets or nests in radial form. These pegmatites show the highest radioactive measurements among the other pegmatite bodies recorded in this area. It is zoned showing pink $\mathrm{K}$-feldspars rich zone in the outer rim and milky quartz rich zone in the inner core, (Fig.3).

Quartz veins are present either as lenses, fine veins and veinlets and fracture fillings cutting all the exposed rocks. They are variable in their dimensions, ranging in length from few meters to 

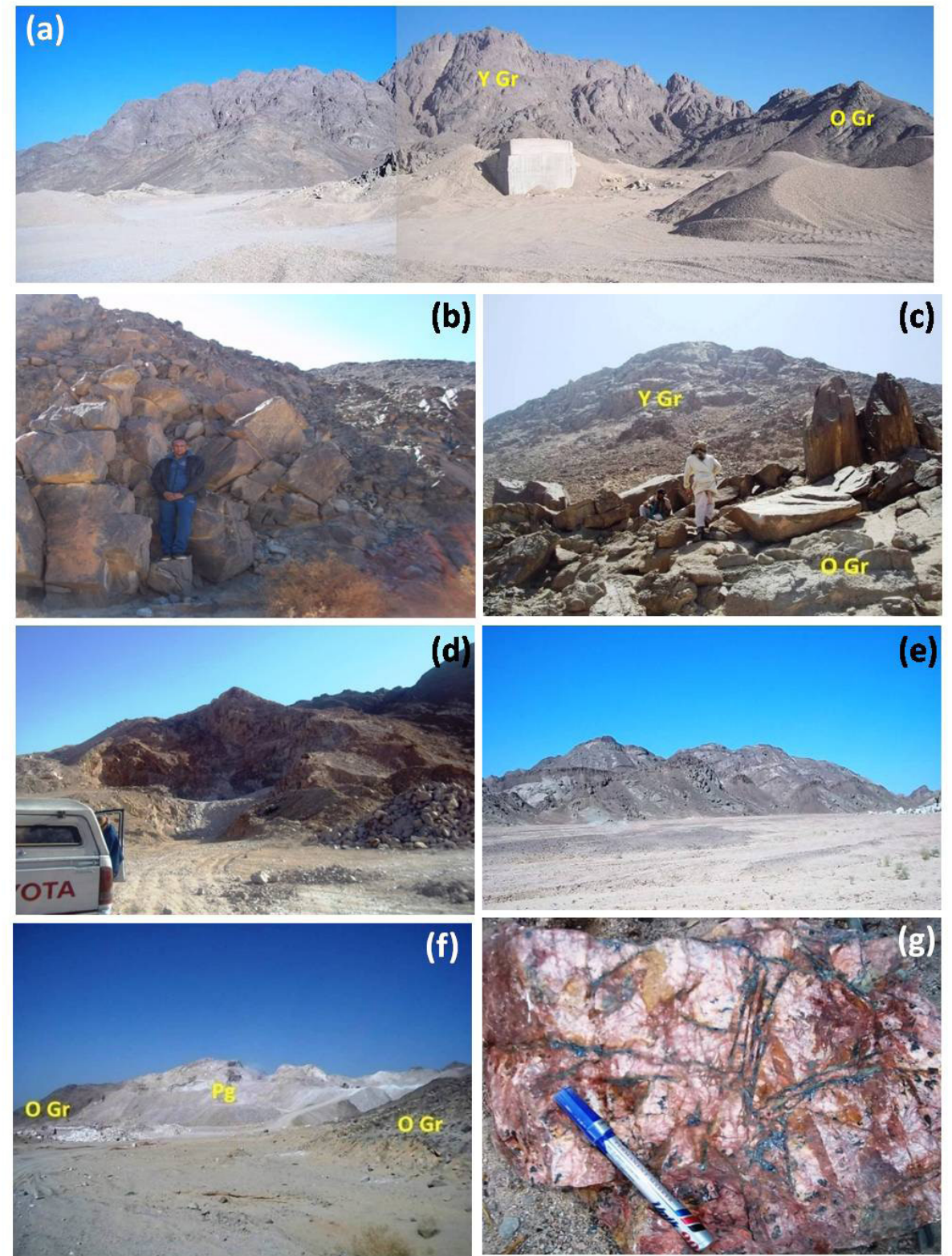

Fig. (2): a): Sharp contact between the younger granites (YGr) and the older granites (OGr) of G. EI Urf, looking NW.

b): Black to gray blocks of the younger gabbros at W. Abu Zawal.

c): Younger granites (Y Gr) of G. El-Dob intruding the older granitoids (O Gr). Looking NW.

d): Semi-rounded pegmatite body intruded in the younger granites, Looking SE

e): Felsite and aplite dike swarms cutting the older granitoids at Gabal El-Urf. Looking NW.

f): Elongated dike-like body of pegmatite (Pg) intruded in the older granitoids (O Gr), Looking NW.

g): Black radioactive minerals as disseminations and fracture filling in W. Abu Zawal pegmatite.

more than 100 meters and in thickness from very thin veinlets to more than one meter. The majority of these quartz veins are striking in NNESSW and NE-SW directions dipping to SSE and SE. They are hard, massive and milky white in colour but sometimes become smoky or with reddish tent.

\section{SAMPLING AND METHODOLOGY}

Nine samples were collected from the pegmatitic rocks of El-Urf area and subjected to petrographical, mineralogical studies and chemical and radiometric analyses. A Nickon polarizing microscope was used for their petrographic investigations.

For the mineralogical investigations, heavy liquids separation technique using bromoform of specific gravity $2.85 \mathrm{gm} / \mathrm{cm}^{3}$ was used to concentrate the heavy minerals. The interesting 


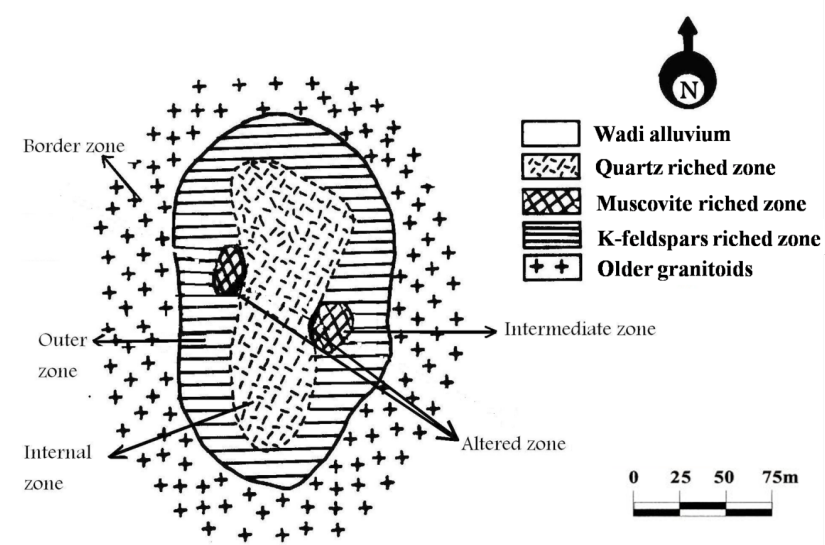

Fig.(3): Sketch for the studied zoned pegmatites at Gabal El-Urf area.

heavy minerals were picked under binocular microscope to obtain pure mineral samples for Xray diffraction (XRD) as well as environmental scanning electron microscope (ESEM) investigation. The XRD technique was used to identify the unknown minerals using PHILIPS diffractometer model PW 3710/31. The ESEM model (PHILIPS XL 30) fitted with energy dispersive $X$-ray (EDAX) unit was used. The EDAX analysis is considered as semi-quantitative analysis since oxygen, carbon and hydrogen are not analyzed. For the radiometric study, a multichannel analyzer Gamma ray spectrometer was used to determine the $\mathrm{eU}$ and eTh concentrations in the laboratory, (Matolin, 1990). All of the previously mentioned analyses were carried out in the Laboratories of the Nuclear Materials Authority of Egypt, (NMA). The X-ray fluorescence technique, (XRF), was used to determine the trace elements contents using PHILIPS spectrometer model PW/2404 at the Department of Earth Sciences, Faculty of Science, Naruto University, Japan. The detection limit for the elements measured by XRF technique is estimated at $1 \mathrm{ppm}$, while it is $1.5 \mathrm{ppm}$ for the elements measured by Gamma ray spectrometry.

\section{PETROGRAPHICAL CHARACTERIS- TICS}

Megascopically, these pegmatites are medium to pegmatitic grained, hard and massive with light colour. Under the microscope, Gabal El-Urf zoned pegmatite is composed essentially of feldspars (at the rim), and quartz at the core. Mica pockets are mostly enriched in the intermediate zone.
Alkali feldspars are represented mainly by orthoclase and microcline perthites. Perthitic intergrowths are of flame and patchy type. Potash feldspars occur as subhedral to anhedral platy crystals enclosing plagioclases, muscovite, biotite, quartz, zircon and opaque iron oxide minerals.

Quartz occurs as anhedral crystals. They are cracked and sometimes intergrown with plagioclases forming myrmekitic texture. Quartz crystals show wavy and undulose extinction and sometimes encloses allanite, sericitized perthitic feldspars and opaque minerals. Quartz occasionally protrude and corrodes plagioclase (Fig.4.a).

Plagioclases $\left(\mathrm{An}_{5-13}\right)$ occur as euhedral to subhedral prismatic megacrystals. They are zoned and commonly twinned according to the albite, carlsbad and pericline laws and slightly altered to sericite and may to carbonates, (Fig.4.c). Occasionally secondary plagioclases occur as fine albite crystals. Plagioclases are unusually cracked and fractured that sometimes filled with needles of uranophane, (Fig.4.b). They also encloses biotite, quartz and opaque iron oxides minerals.

Micas occur as flakes or aggregates of biotite and muscovite. Biotite pleochroic from yellowish brown to dark brown colours and enclosed in plagioclases. It is partially altered to chlorites and iron oxides along its cleavage planes. Biotite encloses quartz, zircon, opaques iron oxides, titanite and apatite.

Muscovite is generally rare in the studied pegmatite filling the plagioclase cracks, (Fig.4.d). The accessory minerals are zircon, apatite, fluorite, titanite and opaques. The thin polished slides, XRD and ESEM analyses indicate that the opaque minerals are magnetite, ilmenite, rutile and goethite.

\section{HEAVY MINERALS INVESTIGATIONS}

It is worth to mention that the concentrate fractions separated from the pegmatitic rocks of El-Urf area are minor. This study aims to identify these separated heavy mineral constituents of the El-Urf pegmatitic rocks in order to estimate their conditions and formation. Three main mineral groups have actually been identified as primary, secondary and gangue mineral groups. 


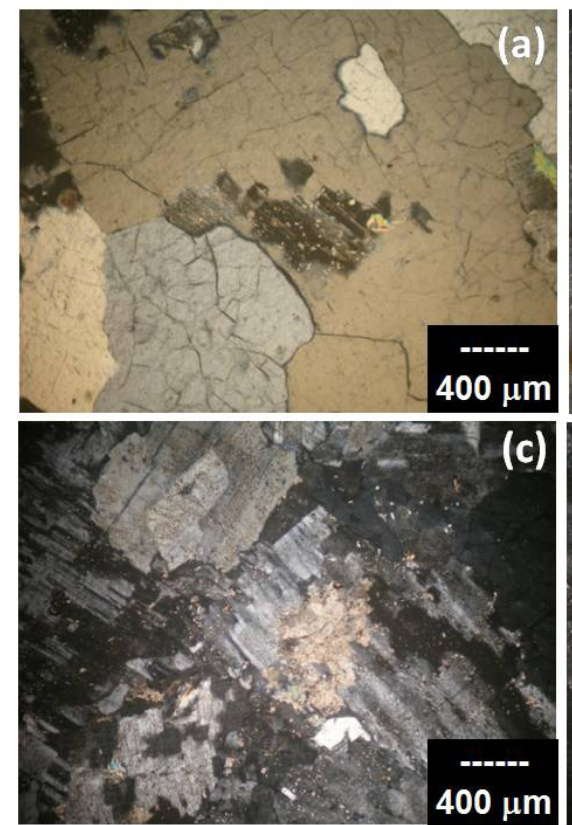

\section{PRIMARY MINERALS}

The primary minerals includes sulphide minerals (pyrite and molybdenite), rutile, magnetite, thorianite, zircon, columbite and garnet.

Pyrite $\left(\mathrm{FeS}_{2}\right)$ represent the most abundant and widespread sulphide mineral. It is easily altered to goethite and/or hematite. Binocular microscope investigations show that pyrite occurs as anhedral fine to medium grains with brownishblack colour and metallic luster, (Fig.5.a). Pyrite has been identified by XRD analysis associating molybdenite (Fig.6.a).

Molybdenite $\left(\mathrm{MoS}_{2}\right)$ is recorded for the first time in El-Urf area as a sulphide mineral. It that can be identified easily by XRD, (Fig.6.a).

Rutile $\left(\mathrm{TiO}_{2}\right)$ is the commonest form of titanium oxide in nature, being the high temperature polymorph. It is very widely distributed as minute grains in many igneous rocks. The rutile occurrence of larger crystals is limited to some granite pegmatites and apatite and quartz veins. Microscopically, rutile grains have deep red brown colour (Fig.5.b). Figure (6.b) shows the X-ray diffraction pattern of rutile associated with ilmenite. ESEM and semi-quantitative EDAX analyses show that it contains $96.43 \%$ of Ti, (Fig.9.a and Table 1) and it has inclusions of zircon.

Magnetite $\left(\mathrm{Fe}_{3} \mathrm{O}_{4}\right)$ is considered as one of the less stable mineral which easily altered to hema-

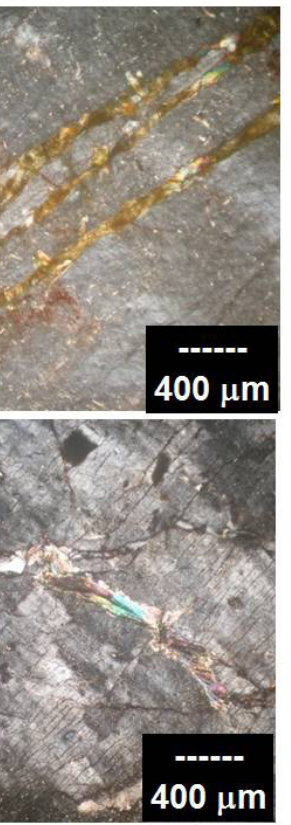

Fig.(4): Cross Nickol Photomicrographs showing:

(a): Plagioclase corroded by cracked quartz.

(b): Fractures in plagioclase megacryst filled with uranophane.

(c): Secondary carbonate after plagioclase.

(d): A fracture in plagioclase filled by secondary quartz and muscovite. tite. The examined magnetite has been separated by hand magnet. Microscopically, magnetite occurs as deep green subhedral crystals, (Fig.5c). Magnetite has been identified by XRD associated with hematite, (Fig.6.c). ESEM and semiquantitative EDAX analyses, (Fig.9.b and Table 1), show that it encloses kasolite.

Thorianite $\left(\mathrm{ThO}_{2}\right)$ is a rare thorium oxide mineral that forms a solid-solution series with uraninite. Microscopically, it has orange colour (Fig.5.d). EDAX semi-quantitative analysis of thorianite (Table 1) shows that it has $67.85 \%$ Th and its uranium content reaches up to about $20.08 \%$.

Zircon $\left(\mathrm{ZrSiO}_{4}\right)$ represents the main constituent mineral in the separated bulk heavy fractions of the studied pegmatite. It is remarkably resistant to attrition and alteration. The recorded zircon particles show pronounced increase in grain size, overgrowth, outgrowth, crystal aggregation and multiple growths. These features resulted from the addition of zirconium transported by the metasomatic agents from the underlying parts of the cataclastic rock on both the pre-existing zircon and the newly formed crystals. Microscopically, zircon has a honey colour (Fig.5.e). XRD pattern of zircon is shown in figure (6.d). ESEM and semi-quantitative EDAX analyses, (Fig.7.c and Table 1), show that the studied zircon has $5.03 \% \mathrm{Hf}$.

Columbite $\left(\mathrm{Fe}^{2+}, \mathrm{Mn}\right)(\mathrm{Nb}, \mathrm{Ta})_{2} \mathrm{O}_{6}$ belongs to 


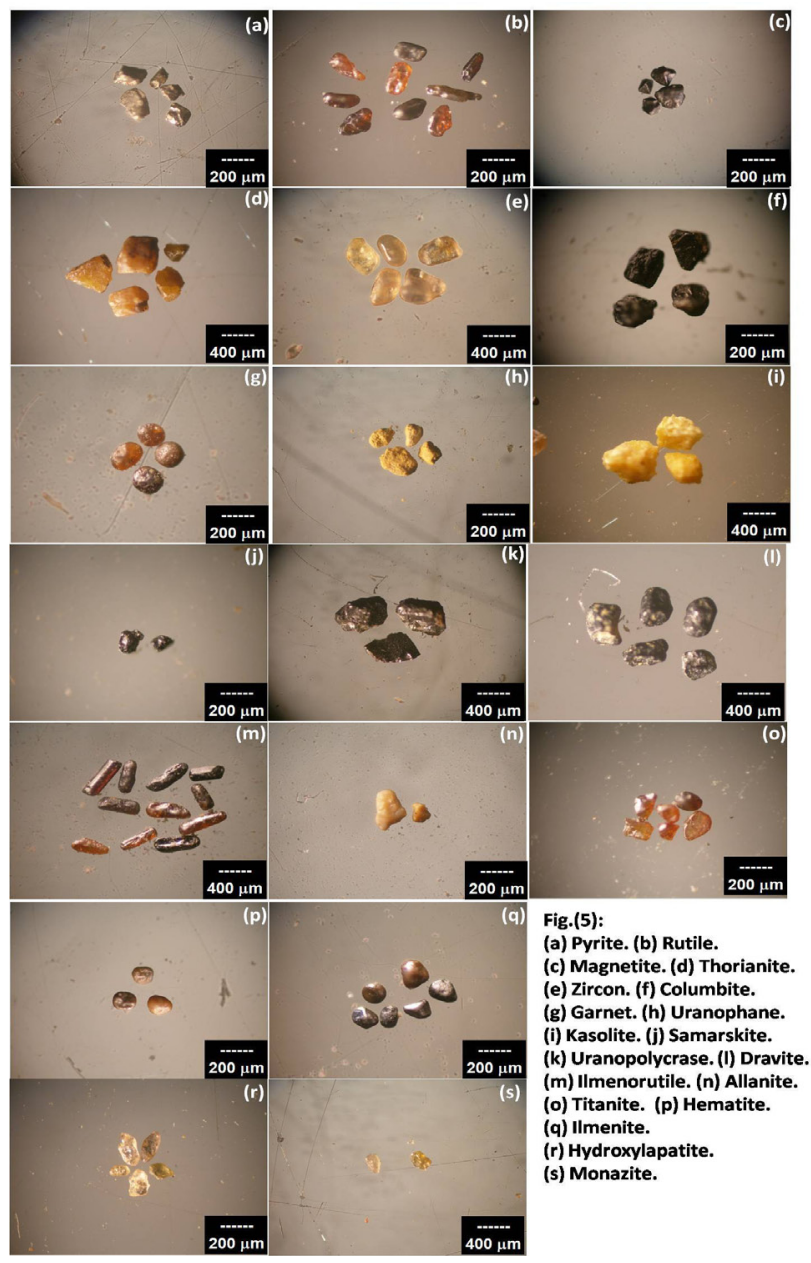

columbite-tantalite series. It is called columbite when niobium predominates. Under the microscope, columbite has deep green colour (Fig.5.f) and the XRD diffractogram of the obtained columbite is shown in figure (6.e). Heinrich (1962) suggested that U-bearing columbite is Ta-poor. $\mathrm{He}$ also stated that the $\mathrm{U}$ content increases with

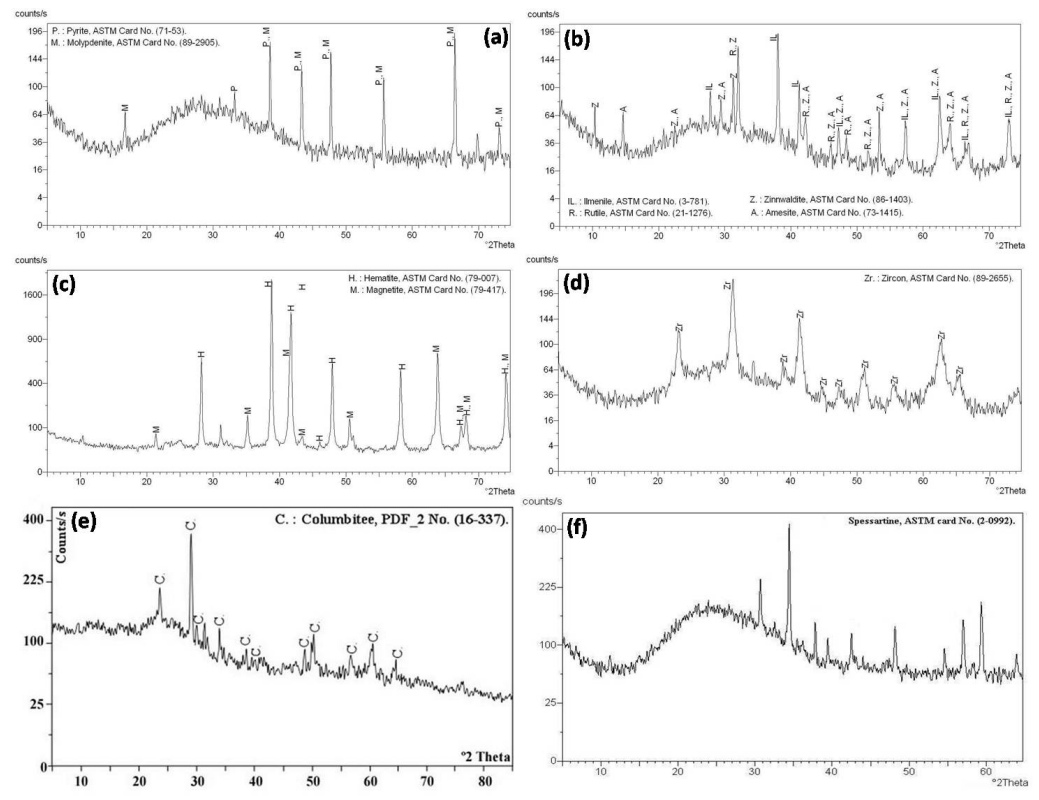

the decreasing temperature of crystallization.

Garnet $\left(\mathrm{Mg}, \mathrm{Fe}_{3}, \mathrm{Mn}_{3}, \mathrm{Ca}_{3}\right) \mathrm{Si}_{3} \mathrm{O}_{12}$ is a group of silicate minerals. All species of garnet posses similar physical properties and crystal forms but differ in chemical composition. Garnet makes up two solid solution series; pyrope-almandine-spessartine and uvarovite-grossularandradite. Garnet is represented in the study area by spessartine $\left(\mathrm{Mn}_{3} \mathrm{Al}_{2} \mathrm{Si}_{3} \mathrm{O}_{12}\right)$ and almandine $\left(\mathrm{Fe}_{2}{ }^{+3} \mathrm{Al}_{2} \mathrm{Si}_{3} \mathrm{O}_{12}\right)$ minerals. Garnet has deep honey colour (Fig.5.g), transparent to translucent with vitreous luster. X-ray diffraction pattern (Fig.6.f) confirmed that the presence of spessartine type, whereas EDAX analysis (Table 1) shows the presence of almandine type while it has $26.94 \%$ of $\mathrm{Fe}$.

\section{SECONDARY MINERALS GROUP}

This group includes uranium minerals (uranophane, kasolite, uranothorite, samarskite and uranopolycrase), dravite, ilmenorutile, allanite and titanite.

Uranophane $\mathrm{Ca}\left(\mathrm{UO}_{2}\right)_{2} \mathrm{SiO}_{3}(\mathrm{OH})_{2 \cdot 5}\left(\mathrm{H}_{2} \mathrm{O}\right)$ is actually the most predominant radioactive mineral in El-Urf area. Under the binocular microscope, it occurs mainly in massive form with yellow colour and dull luster (Fig.5.h) and sometimes it exhibits radiated form. The identification of uranophane has been confirmed by XRD analysis, (Fig.7.a). On the other hand, ESEM and semi-quantitative EDAX analyses, (Fig.9.d and Table 1), show that the separated uranophane has
Fig.(6): X-ray diffraction patterns of: (a) Pyrite associated with molybdenite. (b) Rutile associated with ilmenite, zinnwaldite and amesite. (c) Magnetite associated with hematite. (d) Zircon. (e) Columbite. (f) Garnet of spessartine type. 
$\mathrm{UO}_{2}$ content reaching up to $64.18 \%$.

Kasolite $\mathrm{Pb}\left(\mathrm{UO}_{2}\right) \mathrm{SiO}_{3}(\mathrm{OH})_{2}$ is recorded for the first time in El-Urf area. It is a less common secondary uranium mineral in the studied area. Microscopically, kasolite occurs as massive granular masses having resinous to greasy luster and lemon yellow colour, (Fig.5.i). Figure (7.b) shows the XRD pattern of the study kasolite associated with muscovite, albite and clinochlore. Kasolite is found as separate mineral or enclosed in magnetite, (Fig.9.e). ESEM and semi-quantitative EDAX analyses, (Table 1), show that $\mathrm{U}$ concentration in the kasolite enclosed in pyrite reaches $41.38 \%$.

Uranothorite (Th, U, Ce) $\mathrm{SiO}_{4}$ is a uraniumrich variety of thorite, containing up to half of the thorium replaced by uranium. It occurs as minute crystals in the studied pegmatite. Uranothorite have crystals with dark grass green, transparent and well formed euhedral prisms. ESEM and semi-quantitative EDAX analyses, (Fig.9.f and Table 1), show that the separated uranothorite has $\mathrm{U}$ content $12.08 \%$ and $\mathrm{Th}$ reaching up to $77.23 \%$.

Samarskite $\left(\mathrm{Y}, \mathrm{Fe}^{3+}, \mathrm{U}\right)(\mathrm{Nb}, \mathrm{Ta}) \mathrm{O}_{4}$ occurs in rare earth bearing granite pegmatites with other rare minerals. It occurs in association with columbite, zircon, monazite, uraninite, aechynite, magnetite, albite, topaz, beryl, garnet, muscovite and biotite. Microscopically, samarskite has a deep green colour (Fig.5.j).

Uranopolycrase $(\mathrm{U}, \mathrm{Y})(\mathrm{Ti}, \mathrm{Nb}, \mathrm{Ta})_{2} \mathrm{O}_{6}$ is recorded for the first time in El-Urf area. It is a very rare radioactive mineral that belongs to the polycrase group of minerals that include euxenite-polycrase and yttrocrasite. It is metamict mineral found in pegmatites rocks. Polycrase is the end member of an isomorphous series of minerals that are multiple oxides of $\mathrm{Nb}, \mathrm{Ta}$, $\mathrm{Ti}$ and $\mathrm{Y}$ and usually contain $\mathrm{U}$, Th and REE, so it is one of several minerals called rare earth oxides.

Black radioactive uranopolycrase has been recorded in the studied pegmatitic rocks (Fig.5.k). $\mathrm{X}$-ray diffraction analysis detected the presence of uranopolycrase mineral (Fig.7.c). ESEM and semi-quantitative EDAX analysis (Fig.9.g and Table 1) show that the studied uranopolycrase has $\mathrm{U} 38.63 \%, \mathrm{Nb} 20.60 \%$, Y $9.21 \%$ and $\mathrm{Ta}$ $1.65 \%$.

Dravite $\mathrm{NaMg}_{3} \mathrm{Al}_{6} \mathrm{~B}_{3} \mathrm{Si}_{6} \mathrm{O}_{27}(\mathrm{OH}, \mathrm{F})_{4}$ is one of the tourmaline members and known as magnesian tourmaline. It is recorded for the first time in El-Urf area. Under the microscope, dravite has black colour crystals with vitreous luster, (Fig.5.1). Dravite is identified by X-ray diffraction (Fig.7.d) associated with rutile. ESEM and semi-quantitative EDAX analysis (Fig.9.h and Table 1) show that the studied dravite has traces of Ti and Ca.
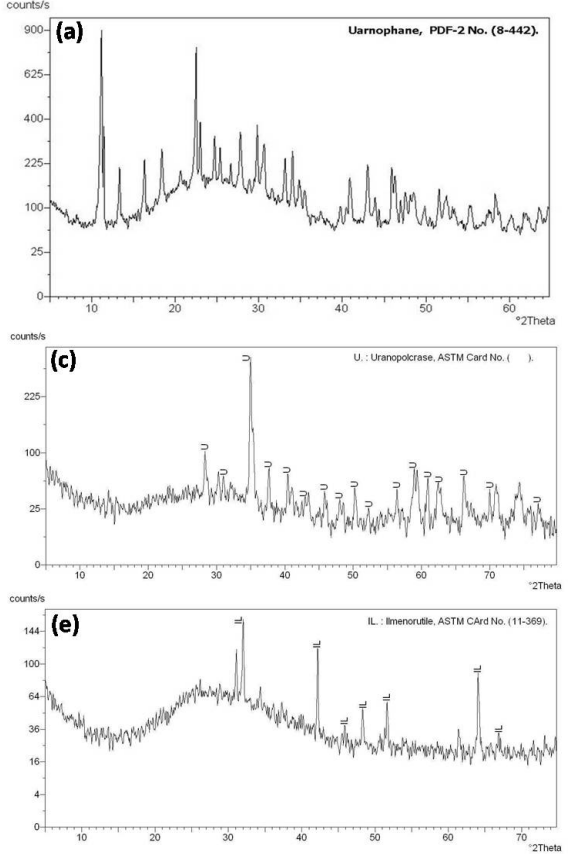
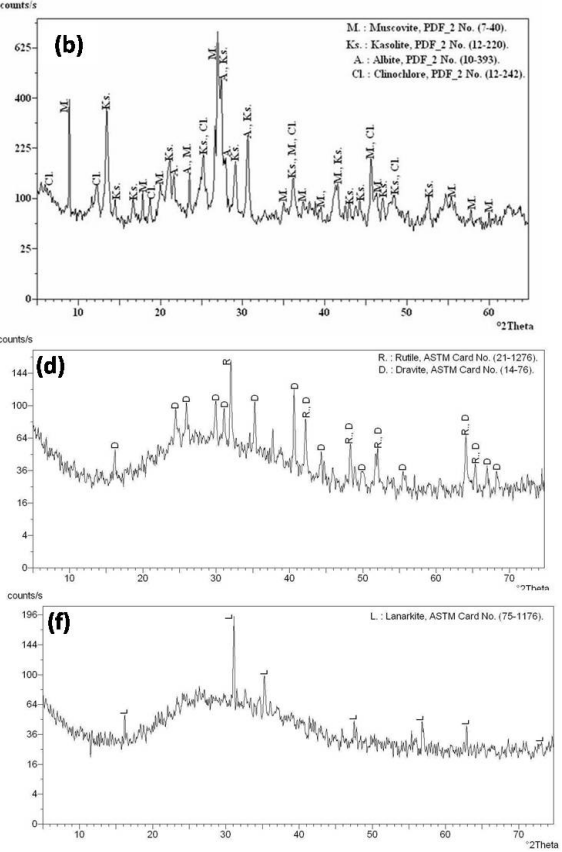

Fig.(7): X-ray diffraction patterns of: (a) Uranophane. (b) Kasolite associated with muscovite, albite and clinochlore. (c) Uranopolycrase. (d) Dravite associated with rutile. (e) Ilmenorutile. (f) 
Ilmenorutile $\left(\mathrm{Ti}, \mathrm{Nb}, \mathrm{Fe}^{3+}\right) \mathrm{O}_{2}$ is a niobian variety of rutile. It is a product of ilmenite-rutile intergrowths. Microscopically, ilmenorutile has prismatic shape and of deep brown colour, (Fig.5.m). Figure (7.e) shows the XRD pattern of ilmenorutile whereas figure (9.i) shows the BSE image of the studied ilmenorutile.

Allanite $(\mathrm{Ca}, \mathrm{Ce})_{2}\left(\mathrm{Fe}^{2+}, \mathrm{Fe}^{3+}\right) \mathrm{Al}_{2} \mathrm{O} . \mathrm{OH}\left[\mathrm{Si}_{2} \mathrm{O}_{7}\right]$ $\left[\mathrm{SiO}_{4}\right]$ is the only member of the epidote group in which $\mathrm{Fe}^{2+}$ is an essential component. Radioactive components are usually present in allanite which it contains Th and U. Allanite occurs commonly in the metamict state due to the partial destruction of its crystalline structure. Microscopically, allanite crystals are of yellowish colour, (Fig.5.n). ESEM and semi-quantitative EDAX analysis of allanite (Fig.9.j and Table 1) show that the studied allanite has $26.75 \% \mathrm{Ce}$ and $14.67 \%$ Nd. Yuanming and Michael, (1991) stated that the Ce-rich allanite indicates the muchlocalized remobilization and concentration of REE during a late hydrothermal alteration.

Titanite $\mathrm{Ca} \mathrm{Ti}\left(\mathrm{SiO}_{4}\right)(\mathrm{O}, \mathrm{OH}, \mathrm{F})$ is a widespread accessory mineral of igneous rocks and it is the dominant titanium-bearing mineral. It is commonly present as rare earth metals bearing minerals including cerium and yttrium. Calcium may partly be replaced by thorium. Deer et al., (1979) stated that the alteration product of titanite is present as rutile which has considerable amounts of $\mathrm{Nb}$ and $\mathrm{Ta}$. Titanite is characterized by rhombic or sphenoidal shape with yellowish brown colour (Fig.5.o). In general, The colour of titanite depends on its Fe content. ESEM and semi-quantitative EDAX analyses, (Fig.9.k and Table 1) indicate that the studied titanite grains have Fe, $\mathrm{U}$ and Th contents of 9.10, 6.92 and $4.71 \%$ respectively...

\section{GANGUE MINERALS GROUP}

The gangue minerals group associating the economic heavy minerals includes the sulphate minerals (lanarkite and barite), the iron oxide minerals (hematite, ilmenite and goethite) as well as phosphate minerals (apatite, monazite and kamitugaite).

Lanarkite $\mathrm{Pb}_{2}\left(\mathrm{SO}_{4}\right) \mathrm{O}$ is identified for the first time in El-Urf area. The XRD diffractogram
(Fig.7.f) shows the presence of lanarkite. It is the oxidation product of galena.

Barite $\left(\mathrm{BaSO}_{4}\right)$ can be identified microscopically as platy fine yellowish grains. The XRD diffractogram (Fig.8.a) shows the pattern of the barite mineral from the studied area. ESEM and the semi-quantitative EDAX analyses, (Fig.9.1 and Table 1) show that the studied barite is stained by iron oxide has $4.58 \%$ of $\mathrm{Zn}$.

Hematite $\left(\mathrm{Fe}_{2} \mathrm{O}_{3}\right)$ is the most abundant and pervasive iron oxide. It occurs as euhedral crystals of dull red colour (Fig.5.p). The XRD analysis shows that the studied hematite associates magnetite, (Fig.6.c). ESEM and semi-quantitative EDAX analyses of the investigated hematite, (Fig.9.m and Table 1), show that it has minute amounts of $\mathrm{Zn}$ and $\mathrm{Pb}$.

Ilmenite $\left(\mathrm{FeTiO}_{3}\right)$ is a titanate of ferrous iron and common as accessory mineral in many igneous rocks. Microscopically, ilmenite has a dull dark colour (Fig.5.q). The X-ray diffraction pattern of the studied ilmenite associated to rutile, zinnwaldite and amesite is shown in figure (6.b). ESEM and semi-quantitative EDAX analyses, (Fig.9.n and Table 1), show that its $\mathrm{Fe}$ and $\mathrm{Ti}$ contents reach $46.56 \%$ and $41.36 \%$ respectively.

Goethite $(\mathrm{FeO} . \mathrm{OH})$ is a very common mineral occurring typically as a weathering product of iron-bearing minerals. It is normally formed under oxidizing conditions and includes much materials classed as limonite (Deer et al., 1979). In the studied area, goethite represents the final stage of the alteration of the pre-existing iron minerals as magnetite and pyrite due to oxidation and hydration processes. XRD pattern of the studied goethite is shown in figure (8.b). Semiquantitative EDAX analyses of the study goethite, (Table 1), show that it has Si up to $8.02 \%$ forming admixture and impurity in the mineral, (Deer et al., 1979).

Apatite $\mathrm{Ca}_{5}\left(\mathrm{PO}_{4}\right)_{3}(\mathrm{OH}, \mathrm{F}, \mathrm{Cl})$ is a common accessory phosphate mineral in many rock types and is the most abundant phosphorous bearing mineral. Apatite is a series includes fluorapatite, chlorapatite, hydroxylapatite and carbonateapatite. The fluorine, chlorine, hydroxyl, and carbonate substitute for one another, so in na- 
Fig.(8): X-ray diffraction patterns of: (a) Barite. (b) Goethite. (c) Fluorapatite. Hydroxylapatite associated with quartz. (e) Monazite. (f) Kimatugaite associated with montmorillonite.
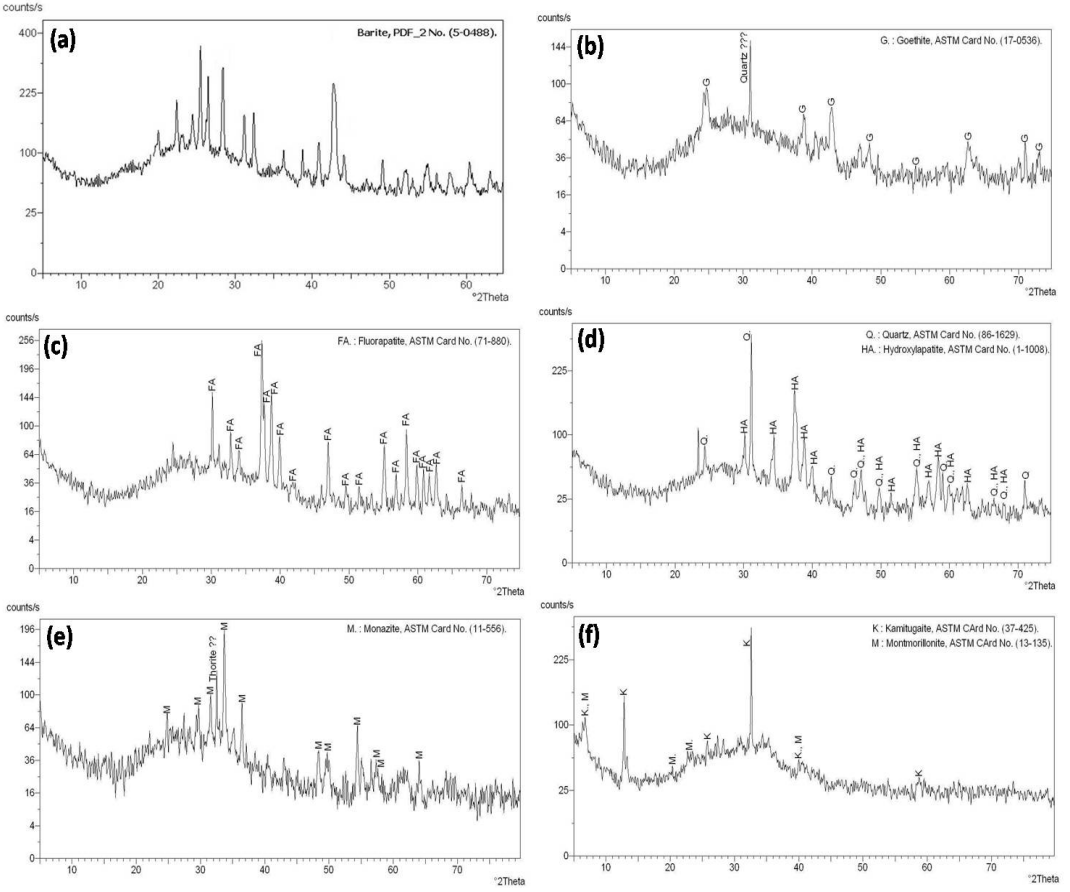

ture most apatite is a mixture of several of these compounds. The intensity of the apatite colour increases with an increase in Mn content (Deer et al., 1979). Microscopically, apatite presents as thick tabular crystals (Fig.5.r), with white to yellow colour. The X-ray diffraction recorded that apatite is represented mainly by fluorapatite mineral (Fig.8.c) and hydroxylapatite mineral (Fig.8.d). ESEM and semi-quantitative EDAX analysis (Fig.9.o) show that the hydroxylapatite in the studied area contains $62.98 \%$ of $\mathrm{Ca}$.

Monazite $(\mathrm{Ce}, \mathrm{La}) \mathrm{PO}_{4}$ is brown to reddish brown in colour (Fig.5.s) and usually forms early in the crystallization sequence of pegmatite but may persist until the core margin/pocket zones of some pegmatite (Simmons et al., 2003). Cemonazite is predominant in the studied pegmatite. Monazite crystals are found in appreciable amount, characterized by their relative coarse size. X-ray diffraction pattern of monazite is shown in figure (8.e).

$\begin{array}{llll}\text { Kamitugaite } \quad \mathrm{Pb} & \mathrm{Al}\left(\mathrm{UO}_{2}\right)_{5} & {\left[(\mathrm{P}, \mathrm{As}) \mathrm{O}_{4}\right]_{2}}\end{array}$ $(\mathrm{OH})_{9} \cdot 9.5\left(\mathrm{H}_{2} \mathrm{O}\right)$ is recorded for the first time in El-Urf area. It is a uranium bearing phosphate minerals. XRD pattern (Fig.8.f) confirmed the presence of kamitugaite in the studied area associated with montmorillonite.

\section{RADIOACTIVITY}

Radioactivity of Gabal El-Urf pegmatites has been discussed by many authors. A trace elements, eU and eTh contents of nine samples representing the studied pegmatitic rocks of El-Urf area were analyzed, (Table 2).

The studied pegmatitic rocks of El-Urf area can be divided into two separate groups; the first one is the mineralized pegmatites which they posses U-mineralization and the second is the non-mineralized pegmatites that they show lower U-content than the first group. The mineralized pegmatites have eU content ranging from 95 to $3107 \mathrm{ppm}$ and eTh content ranging from 46 to $862 \mathrm{ppm}$ with $\mathrm{eTh} / \mathrm{eU}$ ratio ranging from 0.22 to 1.96 . The non mineralized pegmatites have eU content ranging from $\mathrm{n}$.d to $16 \mathrm{ppm}$ and eTh content ranging from 3 to $46 \mathrm{ppm}$ with eTh/eU ratio up to 1.19 . The high eU content in the mineralized samples is mainly restricted in the altered zone of this zoned pegmatite and that can be attributed to the presence of the uranium minerals or uranium bearing minerals formerly discussed.

\section{TRACE ELEMENTS}

The pegmatites of Gabal El-Urf area show highly alteration, uranium enrichment and a strong enrichment in some rare metal (which $\mathrm{Zr}$, $\mathrm{Y}, \mathrm{Nb}$, Th and eU reaching up to 557.2, 668.8, $759.1,730.4$ and $3107 \mathrm{ppm}$ respectively), Table (2). Figure (10) is a 3D histogram illustrates the trace elements values for the zoned pegmatites of 

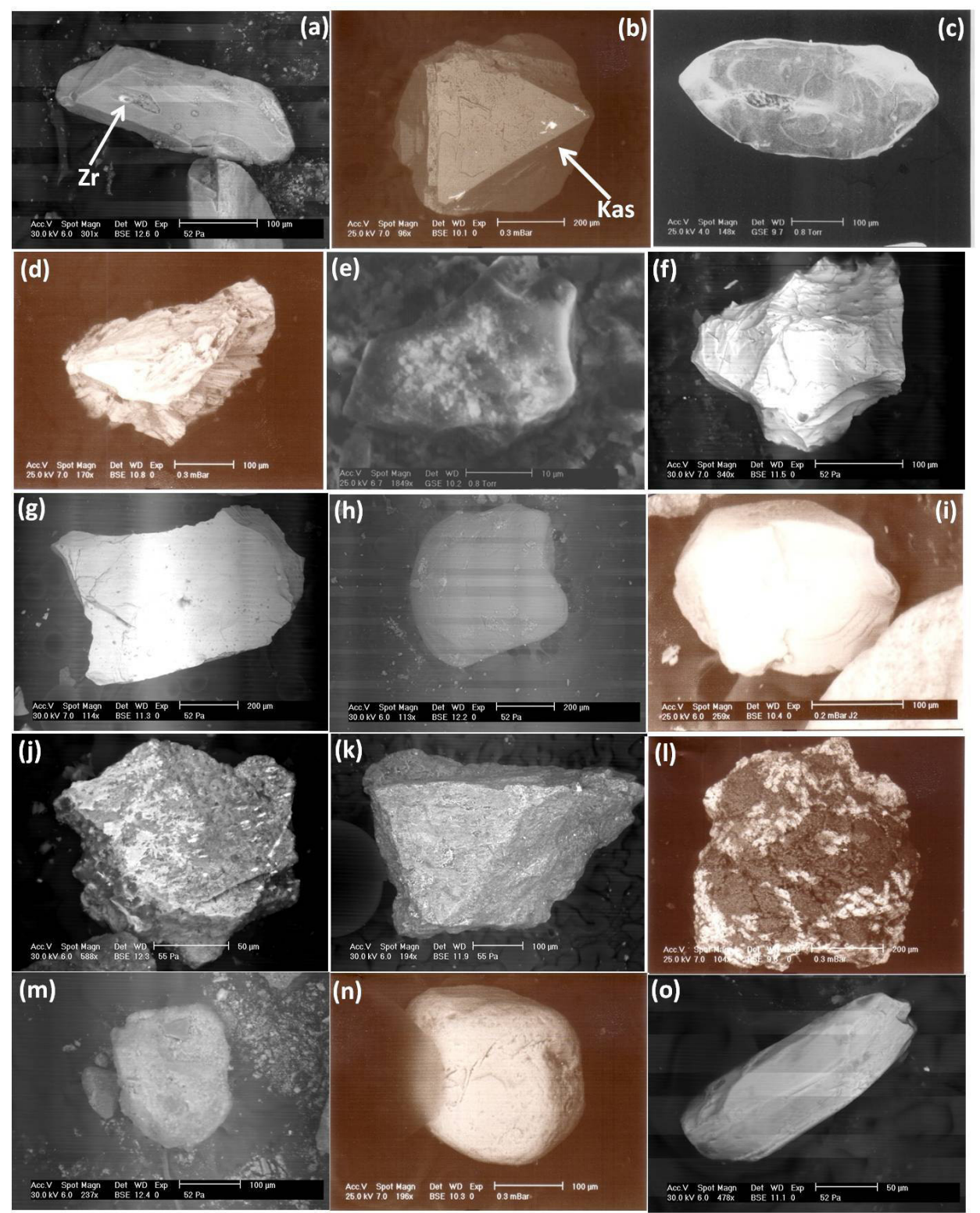

Fig.(9): BSE of (a) Rutile encloses zircon (Zr). (b) Magnetite encloses kasolite (Kas).

(c) Zircon. (d) Uranophane. (e) Kasolite. (f) Uranothorite. (g) Uranopolycrase. (h) Dravite.

(i) Ilmenorutile. (j) Allanite. (k) Titanite. (I) Barite. (m) Hematite. (n) Ilmenite. (o) Hydroxyl

\section{Apatite.}

El-Urf area. The high content in some rare metal in these pegmatites is due to the hydrothermal fluids lead to the intense alteration of these pegmatites represented by hematitization alteration process. This alteration acts as a trapped phase and carrier for some rare metal mineralizations enriched these pegmatites. So, these hydrothermal fluids are potentially important in the dissolution, transportation and precipitation of these elements in these pegmatites.

\section{DISCUSSION}

Cathelineau (1987) stated that the uranium mineralization is affected by the different altera- tion stages, these stages of leaching; mobility and redeposition of $U$ are affected by hydrothermal solutions and supergene fluids causing oxidation of the medium. The origin of the secondary uranium minerals in El-Urf pegmatite (uranophane, kasolite, uranothorite as well as uranopolycrase) is mostly due to the alteration process of the primary minerals by the action of the oxidizing fluids and mobilization of uranium and then redeposition in other forms. Rismaite (1977) stated that, kasolite ranks second in abundance after uranophane and beta-uranophane that is occurred in pegmatites and formed under oxidizing conditions. 
Table (2): Trace elements (ppm) concentrations of the studied pegmatitic rocks.

\begin{tabular}{|c|c|c|c|c|c|c|c|c|c|}
\hline $\begin{array}{c}\text { Sample } \\
\text { No. }\end{array}$ & $1^{\prime}$ & $4^{\prime}$ & $5^{\prime}$ & 7 & 8 & 10 & 16 & 20 & 21 \\
\hline $\mathrm{Ce}$ & 19.3 & 7.0 & 103.9 & 5.8 & 19.7 & 117.8 & 523.5 & 173.8 & 346.9 \\
\hline $\mathrm{Cr}$ & 90.0 & 19.9 & 105.8 & 119.8 & 165.5 & 98.5 & 19.8 & 69.7 & 3.4 \\
\hline $\mathrm{Nb}$ & 31.2 & 0.3 & 219.7 & 2.1 & 32.6 & 100.1 & 650.4 & 516.7 & 759.1 \\
\hline $\mathrm{Ni}$ & 1.2 & n.d & 1.2 & n.d & n.d & 1.1 & 14.7 & 4.0 & 30.2 \\
\hline $\mathrm{Pb}$ & 16.9 & 32.4 & 20.8 & 14.2 & 10.5 & 5.4 & 68.4 & 18.6 & 189.8 \\
\hline $\mathrm{Rb}$ & 117.3 & 357.4 & 81.4 & 161.4 & 163.6 & 174.5 & n.d & 217.4 & n.d \\
\hline $\mathrm{Sr}$ & 106.3 & 17.1 & 18.3 & 159.1 & 20.8 & 27.8 & 44.7 & 19.2 & 35.8 \\
\hline $\mathrm{Th}$ & 15.9 & n.d & 136.2 & 1.1 & 11.7 & 203.2 & 590.3 & 199.4 & 730.4 \\
\hline $\mathrm{Y}$ & 46.0 & 23.0 & 79.8 & 15.8 & 20.5 & 35.0 & 324.9 & 114.4 & 668.8 \\
\hline $\mathrm{Zr}$ & 66.1 & n.d & 7.8 & 5.0 & 41.4 & 557.2 & 46.9 & 11.0 & 91.5 \\
\hline $\mathrm{Ba}$ & 254.2 & 48.7 & 20.2 & 492.7 & 62.8 & 58.6 & n.d & 5.3 & n.d \\
\hline $\mathrm{eU}$ & 285 & n.d & 95 & n.d & 16 & 135 & 905 & 9 & 3107 \\
\hline $\mathrm{eTh}$ & 62 & 3 & 46 & 4 & 19 & 265 & 762 & 46 & 862 \\
\hline eTh/eU & 0.22 & --- & 0.48 & --- & 1.19 & 1.96 & 0.84 & 5.11 & 0.28 \\
\hline
\end{tabular}

- n.d means not detected.

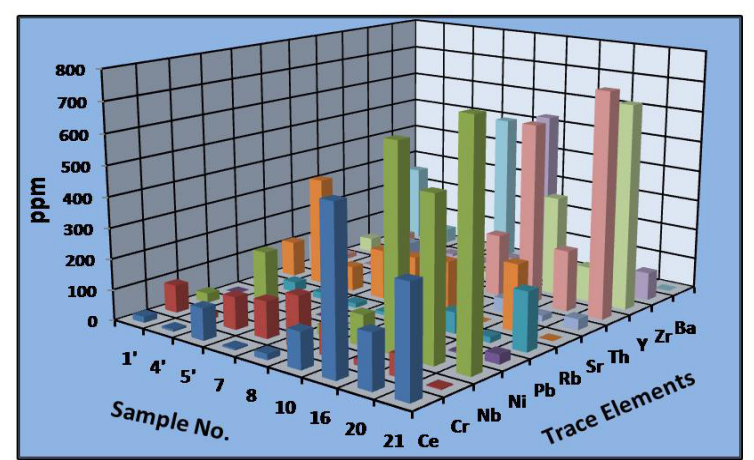

Fig.(10): Histogram shows the trace elements content in the studied El-Urf zoned pegmatites.

Rogers and Adams (1969) stated that the uranium and thorium elements tend to concentrate in the residual phases and then enter the accessory minerals such as zircon and monazite. Also, they may form minerals of their own such as thorianite and uranothorite.

Simpson et al., (1979) shown that the accessory minerals and their sequence of crystallization play a major role in controlling the geochemical behavior of uranium and thorium in silicate melts. The early crystallization of uranothorite would lead to significant U-enrichment in the residual fluids. On the other hand, the early crystallization of zircon and/or xenotime would lead to Th-enrichment in the residual fluids, (Pagel, 1982).

Sminov (1984) suggested that the low Th/U ratio (less than 3 ) in granitic rocks is due to the - ce effect of fluids carrying uranium mineralization. - cr The studied pegmatite rocks have $\mathrm{Th} / \mathrm{U}$ ratio less - Ni than 3 (except one sample) indicating the high - pb effect of hydrothermal solutions. The accessory - $\mathbf{k b}$ minerals such as zircon, monazite, samarskite - $\mathbf{m}$ and columbite as well as thorianite, uranothorite $\forall$ are main sources of the potential radioactivity in Ba the studied pegmatites.

\section{CONCLUSIONS}

Gabal El-Urf zoned pegmatites are composed of extremely milky quartz enriched core, intermediate enriched mica zone and the wall zone that composed mainly of feldspars. These zoned pegmatites hosting or acting as a source for uranium and rare metals ( $\mathrm{Zr}, \mathrm{Y}, \mathrm{Nb}$ and $\mathrm{Th}$ ) mineralizations. Multistage deformation, magmatic and hydrothermal processes accompanied by events of uranium mineralization with the associated rare metals mineralizations in different episodes affected Gabal El-Urf zoned pegmatites.

There is increasing evidences in our study that the rare metals can be originated through magmatic and hydrothermal fluids under the restrictive sets of conditions that commonly prevail in these zoned pegmatites. Our study has provided evidence of magmatic processes which resulted in the presence of primary minerals such as sulphide minerals (pyrite and molybdenite), 
rutile, magnetite, thorianite, zircon, columbite and garnet. The study also has provided the evidences of the secondary minerals to be present as overgrowth minerals (zircon, uranophane, kasolite, uranothorite, samarskite, uranopolycrase, dravite, ilmenorutile, allanite and titanite).

Mineralogical studies are also providing evidences for hydrothermal fluids; plagioclases are unusually cracked and fractured sometimes filled with needles of uranophane. Micas are partially altered to chlorites and iron oxides along its cleavage planes. All these evidences proved that magmatic and hydrothermal processes enriched with rare metals mineralization accompanied by event of an intensive tectonic structure affected Gabal El-Urf pegmatites.

\section{ACKNOWLEDGEMENTS}

I am indebted to Prof. Sayed A. Omar of NMA for his endless assistance during the preparing of this paper and also to Ass. Lecturer Doaa A. Mostafa of NMA for assistance in the mineralogical studies.

\section{REFERENCES}

Abdel Ghani, I.M., 2001, Geology, petrology and radioactivity of Gabal El-Urf area, Central Eastern Desert, Egypt, Ph.D. Thesis, Fac. Sci., South Valley Univ. (Sohag Branch), Egypt, 272p.

Asran, A.M., El-Mansi, M.M., Ibrahim, M.E. and Abdel Ghani, I.M., 2013, Pegmatites of Gabal El-Urf, Central Eastern Desert, Egypt. The 7th Inter. Conf. Geol. Afr., Assuit Univ., Egypt, IV.1-IV.22.

Bishady, A.M., Attawiya, M.Y., Attia, G.M. and El-Nahas, A.A., 1999, Petrographical and geochemical studies on Abu Zawal pegmatites and their host rocks, Central Eastern Desert, Egypt. The 4th Inter. Conf. on Geol. of The Arab World, Cairo Univ., Egypt, 1, 222-245.

Cathelineau, M., 1987, U-Th-REE mobility during albitization and quartz dissolution in granitoids: Evidence from Southeast French Massif Central. Bull. Min., 110, 249-259.

Deer, W.A., Howie, R.A. and Zussman, J., 1979, An Introduction to The Rock Forming Minerals. Longman, London, 528p.

El-Azab, A., 2011, Contribution to the mineralogy and radioactivity of stream sediments of Gabal El-Urf area, Eastern Desert, Egypt. Arab Jour. Geosc. (In press).

El-Mansi, M.M. and Dardier, A.M., 2005, Contribution to the geology and radioactivity of the older granitoids and younger granites of Gabal El-Urf-Gabal Abu Shihat area, Eastern Desert, Egypt. Delta Jour. Sci., 29, 1-17.
El-Taher, M.A., 1978, Relation between geology and radioactivity of some basement rocks to the north of QenaSafaga asphaltic road, Eastern Desert, Egypt. M.Sc. Thesis, Fac. Sci., Al-Azhar Univ., Egypt, 101p.

Habib, M.E., 1982, Landsat investigation of mineralized granites in the area between Gabals El-Urf and ElErediya due to west of Safaga, Egypt. The 8th International Symposium on Machine Processing of Remotely Sensed Data, LARS/Purdue Univ., west Lafayette, U.S.A., 441-446.

Heinrich, E. W., 1962, Radioactive columbite. Am. Mineral., 47, 1363-1379.

Khaleal, F.M., 2013, Granites of Gabal El-Dob area and associated pegmatites, Central Eastern Desert, Egypt: Geochemistry and spectrometry. Nucl. Sci. Scient. Jour., 3, 15-25.

Khamis, H.A., 2012, Structural and radiometric studies of the Precambrian rocks of Wadi Fatira El Zarqa area, Central Eastern Desert, Egypt. Ph.D Thesis, Fac. Sci., Cairo Univ., Egypt, 299p.

Matolin, M., 1990, Construction and use of spectrometric calibration pads, Laboratory gamma-ray spectrometry. A report to the government of the Arab Republic of Egypt, Framework of The IAEA Project, EGY/4/03003.

Pagel, M., 1982, The mineralogy and geochemistry of uranium, thorium and rare earth elements in the two radioactive granites of the Vosages, France. Mineral. Mag., 46, 149-161.

Rismaite, J., 1977, Mineral assemblages at the Rabbit Lack uranium deposit, Sastchwan, Canada. Geol. Surv. Can., I.B, 235-246.

Rogers, J.J. and Adams, J.S.S., 1969, Uranium. In: wedepohl, K.H. (ed.), Handbook of Geochemistry, SpringerVerlag, Berlin, 2 (I), Chap.12, 50p.

Simmons, W.K., Webber, K., Alexander, U.F. and James W.N., 2003, Pegmatology: pegmatite mineralogy, petrology and petrogenesis, Department of Geology and Geophysics. Rubellite Press, Karen L. Webber, 176p.

Simpson, P.R., Brown, G.C., Plant, J. and Ostle, D., 1979, Uranium mineralization and granite magmatism in the British Isles. In: Bowie, S.H.U., Fyfe, W.S., Ostle, D., Plant, J. and Simpson, P.R. (Eds.), Theoretical and practical aspects of uranium geology, Trans. Roy. Soc., London, 291A, 385-412.

Sminov, S.D., 1984, U-Th-RE mobility in granitic environments at the hydrothermal stage. IAEA, Vienna, 215246.

Yuanming, P. and Michael, E.F., 1991, Anadian allanite(La) and anadian allanite-(Ce) from the Hemlo Gold Deposit, Ontario, Canada. Mineral. Mag., 55 (381), 497-507. 